\title{
ANALISIS KEMAMPUAN PENALARAN INDUKTIF MATEMATIS MAHASISWA PENDIDIKAN MATEMATIKA UNIVERSITAS PAPUA
}

\author{
Septian Woro Drupadi dan Jeinne Mumu \\ Universitas Papua
}

Email: j.mumu@unipa.ac.id

\begin{abstract}
This research was conducted to analyze the mathematical Inductive reasoning abilities of students' mathematics education UNIPA. Research on inductive mathematical reasoning skills using qualitative methods using observation techniques, tests and interviews. The results showed that the mathematical inductive reasoning abilities of mathematics education students UNIPA were mostly in the moderate category. Students' inductive reasoning ability on each indicator is the ability to present mathematical statements in writing or drawings of $66.66 \%$, the ability to submit suspicions by $26.66 \%$, mathematical manipulation ability of $29.44 \%$, ability to compile evidence, provide reasons or evidence for some solutions of $5.82 \%$, finding patterns or traits of mathematical symptoms to generalize of $30.27 \%$, examining validity of arguments $11.32 \%$ and drawing conclusions from statements of $5.27 \%$.
\end{abstract}

Kata kunci: inductive reasoning ability, mathematics student.

\section{PENDAHULUAN}

Penalaran sangat penting bagi kehidupan manusia. Proses pengambilan keputusan dan pemecahan masalah menuntut manusia untuk dapat menggunakan kemampuan penalarannya. Menurut Wulandari (2011) Kemampuan bernalar berguna pada saat menyelesaikan permasalahan-permasalahan yang terjadi baik dalam lingkup pribadi, masyarakat dan institusi-institusi sosial lain yang lebih luas. Sejalan dengan pendapat tersebut, Shadiq (2014) juga mengungkapkan pentingnya penalaran yaitu:

"Seni bernalar memang sangat dibutuhkan disetiap segi dan setiap sisi kehidupan ini agar setiap warga bangsa dapat menemutunjukan dan menganalisis setiap masalah yang muncul secara jernih; dapat memecahkan masalah dengan tepat; dapat menilai sesuatu secar kritis dan objektif; serta dapat mengemukakan pendapat maupun idenya secara runtut dan logis". 
Secara garis besar penalaran dapat digolongkan dalam dua jenis yaitu penalaran induktif dan penalaran deduktif. Sebagaimana yang dinyatakan kurikulum 2004 (Depdiknas, 2003). Ciri utama matematika adalah penalaran deduktif, yaitu kebenaran suatu konsep atau pernyataan diperoleh sebagai akibat logis dari kebenaran sebelumnya, sehingga kaitan antar konsep atau pernyataan dalam matematika bersifat konsisten. Namun demikian, dalam pembelajaran, pemahaman konsep sering diawali secara induktif melalui pengalaman peristiwa nyata atau intuisi. Sehingga menurut Shadiq (2014), Penalaran Induktif merupakan suatu aktivitas berfikir untuk menarik suatu kesimpulan atau membuat suatu pernyataan baru yang bersifat umum (general) berdasarkan pernyataan khusus yang diketahui benar. Sedangkan penalaran deduktif merupakan proses berfikir dari bentuk yang umum (aksioma atau postulat) ke bentuk yang khusus.

Di saat belajar matematika, para siswa akan selalu dihadapkan dengan proses penalaran (Shadiq, 2014). Berdasarkan Permendiknas Nomor 22 Tahun 2006 tentang standar isi Mata Pelajaran Matematika, salah satu tujuan pembelajaran matematika adalah agar siswa mampu menggunakan penalaran pada pola dan sifat, melakukan manipulasi matematika dalam membuat generalisasi, menyusun bukti, atau menjelaskan dan pernyataan matematika, namun dari hasil penelitian dari Hiebert dalam (Rosita, 2014) melaporkan bahwa pada umumnya siswa masih menggunakan pemikiran berdasarkan hafalan dibanding melakukan reasoning dalam menyelesaikan permasalahan matematika di kelas. Ditunjukan dengan prestasi siswa Indonesia dalam bidang matematika juga tergolong rendah terbukti menurut Survei terbaru dari Trends International Mathematicd and Science Study (TIMSS) yang dilakukan setiap 4 tahun sekali pada tahun 2015 menempatkan Indonesia pada peringkat 45 dari 50 negara dan pada Programme for International Student Assesment (PISA) pada tahun 2015 Indonesia menduduki rangking 69 dari 76 negara. Berdasarkan hasil study TIMSS pada domain konten materi Geometri memiliki rata-rata persentase $28 \%$ dan domain kognitif pada mata pelajaran matematika rata-rata persentase yang paling rendah pada domain kognitif pada level penalaran yaitu $20 \%$.

Berdasarkan fakta tersebut peneliti tertarik untuk menganalisis kemampuan penalaran induktif matematis dengan menggunakan materi segitiga karena materi segitiga merupakan kompetensi dasar dalam geometri. Menurut Rosnawati (2013) geometri dapat 
dipelajari dengan baik jika siswa mempunyai penalaran yang baik karena matematika dipelajari melalui penalaran, kemampuan penalaran merupakan syarat cukup untuk dapat menguasai matematika. Geometri juga menyediakan konteks yang kaya untuk pengembangan penalaran matematis, termasuk penalaran induksi dan deduksi, membuat dan memvalidasi dugaan serta mengklasifikasikan dan mendefinisikan objek geometri (NCTM, 2000). Namun kenyataannya menurut survey dari TIMSS dan PISA yang diberikan kepada siswa materi geometri dan penalaran masih berada pada level rendah.

Berdasarkan survey yang dilakukan oleh peneliti pada Mahasiswa Pendidikan Matematika Universitas Papua (UNIPA), Indeks Prestasi Kumulatif (IPK) mahasiswa sebagian besar $>3,00$. Hal ini dikarenakan mahasiswa memang suka menghitung dan senang dengan matematika, matematika adalah pelajaran yang tidak perlu dihafal, dan menantang. Berdasarkan informasi yang peneliti peroleh ditemukan juga nilai matematika mahasiswa pada saat masih berada pada bangku sekolah tergolong tinggi. Rata-rata nilai berada diantara 70 - 90. Hal ini menunjukan bahwa kemampuan mahasiswa dalam hal matematika baik.

Berdasarkan uraian diatas maka peneliti tertarik untuk melakukan analisis kemampuan penalaran matematis pada Mahasiswa Pendidikan Matematika Universitas Papua yang diwujudkan dalam sebuah penelitian dengan judul "Analisis Kemampuan Penalaran Induktif Matematis Mahasiswa Pendidikan Matematika Universitas Papua”.

\section{METODE PENELITIAN}

Penelitian ini dilaksanakan di Jurusan Pendidikan Matematika UNIPA kabupaten Manokwari provinsi Papua Barat, pada bulan April 2018. Sebagai subyek penelitian adalah mahasiswa program studi pendidikan matematika UNIPA angkatan tahun 2015, 2016, dan 2017. Metode yang digunakan pada penelitian ini adalah metode kualitatif. Metode ini dilakukan untuk menganalisis data yang dikumpulkan dan ditemukan di lapangan secara lebih mendalam.

Pada penelitian ini data yang diperoleh merupakan hasil tes tertulis yang diberikan kepada mahasiswa, hasil wawancara terhadap 3 mahasiswa yang mempunyai nilai di luar pola umum data, dan data yang merupakan hasil observasi. Penelitian ini juga melakukan triangulasi untuk meningkatkan validitas data. Triangulasi menurut Tanujaya dan Mumu (2016) adalah teknik pemeriksaan keabsahan data yang memanfaatkan sesuatu yang lain 
di luar data itu untuk keperluan pengecekan atau pembanding terhadap data itu. Triangulasi dilakukan dapat dalam beberapa aspek, yaitu: metode, waktu, tempat, sumber data, peneliti, dan teori.

Penelitian ini melakukan triagulasi melalui wawancara dan observasi terhadap hasil tes tertulis. Tes tertulis digunakan dalam penelitian ini bertujuan untuk memperoleh data tentang kemampuan penalaran induktif matematis mahasiswa, dalam bentuk tes uraian (essay). Wawancara dilakukan sebagai cara mendapatkan informasi atau bahan-bahan keterangan yang dilakukan melalui proses tanya jawab lisan secara sepihak berdasarkan tujuan yang telah ditentukan (Atmaja, 2016). Dalam penelitian ini wawancara dilakukan kepada mahasiswa sebagai teknik pendukung selain tes untuk memperoleh gambaran dan informasi yang lebih mendalam untuk menganalisis kemampuan penalaran induktif matematis mahasiswa, yaitu mengetahui alasan mahasiswa dalam menyelesaikan soal.

Data yang diperoleh dianalisis dengan menggunakan model Miles dan Huberman. Aktivitas dalam analisis data menurut Sugiyono (2015) yaitu reduksi data (data reduction), penyajian data (data display) dan kesimpulan/verifikasi (conclusion drawing /verification).

\section{HASIL DAN PEMBAHASAN}

Tes yang telah diberikan kepada 72 mahasiswa yang dikerjakan dalam waktu 90 menit memberikan informasi bahwa dari seluruh mahasiswa yang mengikuti tes tidak ada yang dapat menyelesaikan semua soal dengan benar. Hal ini ditunjukan dengan skor tertinggi yang dapat mahasiswa peroleh adalah 60 dari total skor 100. Berikut ini adalah data persentase jumlah skor mahasiswa yang disajikan dalam bentuk dalam grade, sebagaimana disajikan pada Tabel 1.

Tabel 1. Distribusi skor mahasiswa berdasarkan grade

\begin{tabular}{ccccl}
\hline Nilai Angka & Frekuensi & Persentase & Nilai Huruf & \multicolumn{1}{c}{ Kategori } \\
\hline$\geq 80$ & 0 & $0,00 \%$ & A & Sangat Baik \\
$70-79$ & 0 & $0,00 \%$ & B & Baik \\
$60-69$ & 1 & $1,39 \%$ & C & Cukup \\
$40-59$ & 21 & $29,16 \%$ & D & Kurang \\
$<40$ & 50 & $69,44 \%$ & E & Gagal \\
\hline
\end{tabular}

Berdasarkan Tabel 1, tampak bahwa persentase skor mahasiswa yang paling tinggi adalah 69,44\% yang berarti bahwa sebanyak 50 dari 72 mahasiswa mendapatkan nilai kurang dari 40 sehingga mendapatkan grade penilaian E dengan kategori gagal. Selain 
itu diketahui juga bahwa tidak ada mahasiswa yang mendapatkan grade penilaian A dan B ditunjukan dari Tabel 1, yaitu pada grade A dan B jumlah mahasiswa yang memperoleh nilai tersebut sebanyak 0. Data tersebut lebih jelasnya disajikan pada Gambar 1.

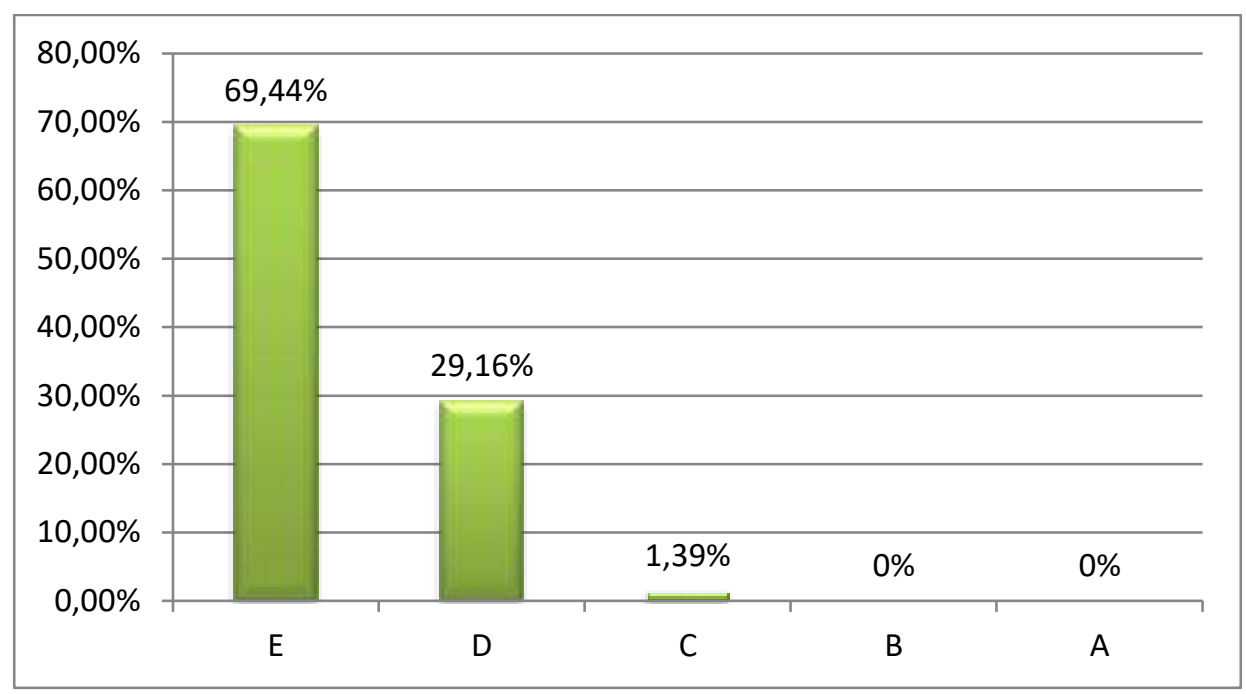

Gambar 1. Distribusi persentase skor mahasiswa berdasarkan grade

Berikut ini skor yang diperoleh mahasiswa ditersajikan dalam bentuk tabel distribusi frekuensi, sebagaimana tampak pada Tabel 2.

Tabel 2. Distribusi skor kemampuan penalaran induktif matematis mahasiswa

\begin{tabular}{cccc}
\hline No & Interval Skor & Jumlah Mahasiswa & Persentase \\
\hline 1. & $0-10$ & 12 & $16.67 \%$ \\
2. & $11-20$ & 12 & $16.67 \%$ \\
3. & $21-30$ & 14 & $19,44 \%$ \\
4. & $31-40$ & 12 & $16.67 \%$ \\
5. & $41-50$ & 12 & $16,67 \%$ \\
6. & $51-60$ & 10 & $13,88 \%$ \\
7. & $61-70$ & 0 & $0,00 \%$ \\
\hline
\end{tabular}

Berdasarkan Tabel 2, dapat dilihat bahwa interval skor hanya sampai 51-60, hal itu dikarenakan tidak ada mahasiswa yang mencapai skor diatas 60. Skor paling tinggi berasal interval 51-60 dengan jumlah sebanyak 10 mahasiswa dan persentasenya sebesar 13,88\%. Skor tertinggi yang diperoleh mahasiswa adalah 60 dan hanya 1 mahasiswa yang memperolehnya. Data tersebut lebih jelas disajikan dalam bentuk grafik pada Gambar 2. 


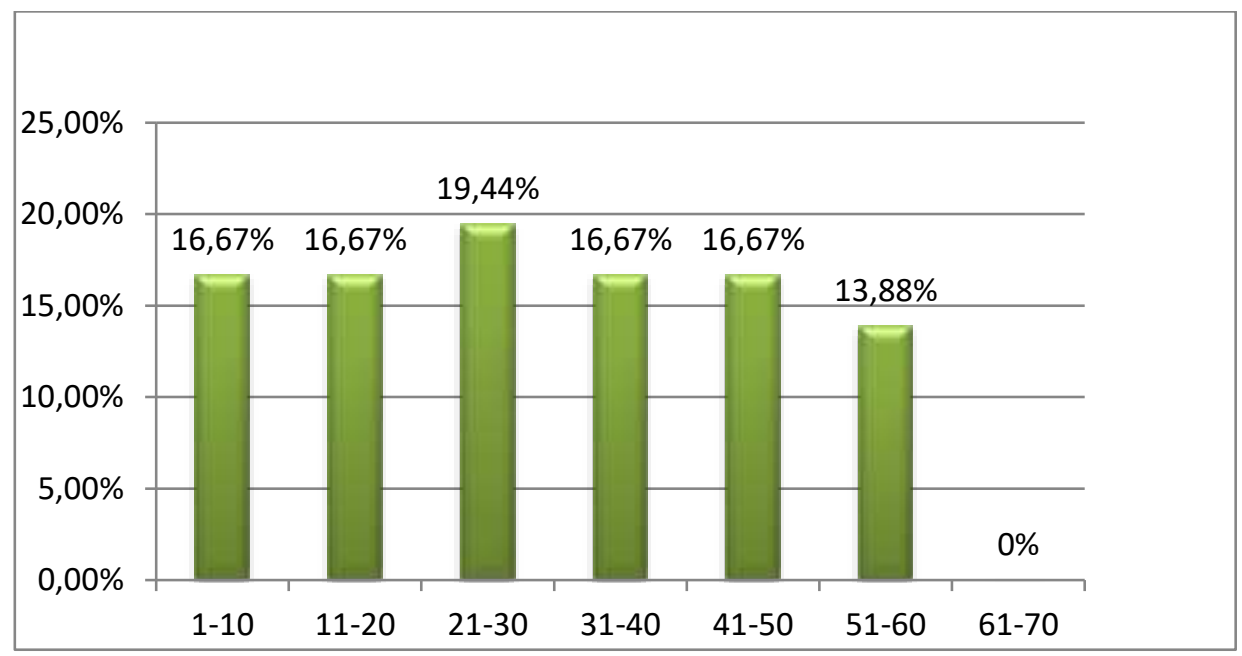

Gambar 2. Distribusi skor kemampuan penalaran induktif matematis mahasiswa

Berdasarkan Gambar 2, dapat dilihat bahwa skor kemampuan penalaran induktif matematis mahasiswa Pendidikan Matematika di Jurusan Pendidikan Matematika adalah $\leq 60$ dari skor total yaitu 100 dengan jumlah mahasiswa yang memperoleh interval skor 51-60 sebanyak 13,88\%. Interval skor yang paling banyak dicapai mahasiswa adalah skor 21-30 dengan persentase mahasiswa sebesar 19,44\% dan selain interval tersebut persentase mahasiswa sama yaitu berasa pada 16,67\%. Berdasarkan grafik persentase perolehan skor mahasiswa di atas menunjukan bahwa kemampuan penalaran matematis mahasiswa rata-rata berimbang pada masing-masing kelas interval.

Berdasarkan data hasil tes tertulis dan uraian diatas skor tertinggi kemampuan penalaran induktif matematis mahasiswa yang dicapai adalah $\leq 60$ (kurang dari atau sama dengan 60). Menurut kriteria evaluasi milik Riduwan (2011) hal tersebut menandakan tingkat kemampuan penalaran mahasiswa pendidikan matematika berada pada kategori sedang yaitu sebanyak 22 mahasiswa dengan skor yang mereka peroleh berada pada interval 41-60 dan itu masuk pada kategori sedang.

Berdasarkan hasil observasi dan tes tertulis ditemukan bahwa mahasiswa yang masuk kedalam kategori kemampuan sedang sebagian besar adalah mahasiswa angkatan 2015 sedangkan mahasiswa yang masuk dalam kategori rendah adalah mahasiswa angkatan 2016 dan sangat rendah adalah mahasiswa angkatan 2017. Hal itu dikarenakan mahasiswa angkatan 2017 adalah mahasiswa baru yang belum terbiasa dengan soal yang menuntut kemampuan penalaran seperti dalam hal pembuktian, menemukan pola, dan menyusun bukti dibandingkan dengan mahasiswa angkatan diatasnya yaitu angkatan 
2016 dan 2015 yang sudah terbiasa dengan soal-soal yang memerlukan penalaran.

Berikut ini disajikan persentase mahasiswa yang mampu melakukan ketujuh indikator penalaran induktif matematis. Tujuh indicator kemampuan penalaran induksi yaitu menyajikan pernyataan matematika secara tertulis dan gambar, mengajukan dugaan, melakukan manipulasi matematika, menyusun bukti, memberikan alasan atau bukti terhadap beberapa solusi, menarik kesimpulan dari pernyataan, memeriksa kesahihan suatu argumen dan menemukan pola atau sifat dari gejala matematis untuk membuat generalisasi pada setiap butir soal yang diberikan dan indikator mana yang paling banyak dilakukan dan yang paling sedikit dilakukan mahasiswa pada setiap butir soal. Distribusi kemampuan penalaran induktif yang mampu dilakukan mahasiswa pada setiap indicator dapat dilihat pada Tabel 3 .

Tabel 3. Distribusi penalaran induktif mahasiswa berdasarkan indikator dan butir soal

\begin{tabular}{cccccccc}
\hline Butir & \multicolumn{7}{c}{ Indikator Kemampuan Penalaran Induktif (\%) } \\
\cline { 2 - 7 } Soal & $\mathbf{1}$ & $\mathbf{2}$ & $\mathbf{3}$ & $\mathbf{4}$ & $\mathbf{5}$ & $\mathbf{6}$ & $\mathbf{7}$ \\
\hline 1 & 87,5 & 47,22 & 62,50 & 2,77 & 48,61 & 38,88 & 2,77 \\
2 & 79,16 & 19,44 & 15,27 & 4,16 & 26,38 & 13,88 & 4,16 \\
3 & 69,44 & 40,27 & 44,44 & 18,05 & 43,05 & 27,77 & 12,50 \\
4 & 41,66 & 0 & 1,38 & 0 & 15,27 & 4,16 & 1,38 \\
5 & 55,55 & 26,38 & 23,61 & 4,16 & 18,05 & 6,94 & 5,55 \\
\hline
\end{tabular}

Berdasarkan Tabel 3, diketahui bahwa pada butir soal 1 persentase indikator kemampuan penalaran yang paling tinggi adalah indikator kemampuan menyajikan pernyataan matematika secara tertulis atau gambar yaitu sebesar $87,5 \%$ sedangkan yang paling rendah adalah indikator kemampuan menyusun bukti, memberikan alasan atau bukti terhadap beberapa solusi sebesar 2,77\% dan indikator kemampuan menarik kesimpulan dari pernyataan sebesar $2,77 \%$.

Pada butir soal 2 persentase indikator kemampuan penalaran yang paling tinggi adalah indikator kemampuan menyajikan pernyataan matematika secara tertulis atau gambar yaitu sebesar 79,16\% sedangkan yang paling rendah adalah indikator kemampuan menyusun bukti, memberikan alasan atau bukti terhadap beberapa solusi sebesar $4,16 \%$ dan indikator kemampuan menarik kesimpulan dari pernyataan sebesar 4,16\%.

Pada butir soal 3 persentase indikator kemampuan penalaran yang paling tinggi adalah indikator kemampuan menyajikan pernyataan matematika secara tertulis atau gambar yaitu sebesar 69,44\% sedangkan yang paling rendah adalah indikator kemampuan menyusun bukti, memberikan alasan atau bukti terhadap beberapa solusi sebesar $18,05 \%$ 
dan indikator kemampuan menarik kesimpulan dari pernyataan sebesar 12,50\%.

Pada butir soal 4 persentase indikator kemampuan penalaran yang paling tinggi adalah indikator kemampuan menyajikan pernyataan matematika secara tertulis atau gambar yaitu sebesar $41,66 \%$ dan terdapat 2 indikator yang tidak dapat dilakukan oleh mahasiswa sama sekali yaitu indikator kemampuan mengajukan dugaan dan indikator kemampuan menyusun bukti, memberikan alasan atau bukti terhadap beberapa solusi.

Pada butir soal 5 persentase indikator kemampuan penalaran yang paling tinggi adalah indikator kemampuan menyajikan pernyataan matematika secara tertulis atau gambar yaitu sebesar 55,55\% sedangkan yang paling rendah adalah indikator kemampuan menyusun bukti, memberikan alasan atau bukti terhadap beberapa solusi sebesar $4,16 \%$ dan indikator kemampuan menarik kesimpulan dari pernyataan sebesar 5,55\%.

Berikut ini disajikan gambar berupa hasil kerja dari responden 1 yaitu salah satu mahasiswa yang berasal dari kategori sedang, untuk soal nomor 1, sebagaimana disajikan pada Gambar 3.

Sebuah $\triangle A B C$ diketahui $\angle A B D=53^{\circ}, \angle D C B=25^{\circ}$ dan $\angle C B D=67^{\circ}$.

Tentukan besar $\angle B A D$.

a. Buktikan jawaban anda.

b. Buatlah kesimpulan.

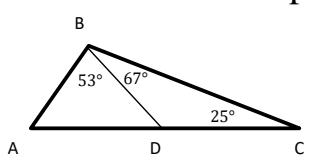

Jawaban Responden (contoh)

$$
\begin{aligned}
& \text {, } \angle A B D=53^{\circ} \quad \angle D=120^{\circ} \\
& \angle D C B=25^{\circ} \\
& \angle C O D \cdot 67^{\circ} \\
& \angle B A C=180^{\circ}-(A B D+C B D+O C B) \\
& \angle B A D=\ldots ? \text {. } \\
& =180^{\circ}-\left(53^{\circ}+67^{\circ}+25^{\circ}\right) \\
& , 180^{\circ}-195^{\circ} \\
& =35^{\circ}
\end{aligned}
$$

Gambar 3. Contoh jawaban soal nomor 1

Berdasarkan hasil tes tertulis pada Gambar 3, tampak bahwa responden mengerjakan soal sesuai petunjuk umum yang diperintahkan yaitu menuliskan apa saja 
yang diketahui dan yang ditanyakan sehingga sudah tau apa yang akan dilakukan untuk menjawab soal. Responden mengajukan dugaan dengan menuliskan jumlah sudut dalam segitiga sebesar $180^{\circ}$ dan menuliskan prosedur pengerjaan yaitu perhitungan matematika dan mendapatkan jawaban akhirnya. Responden tidak melakukan indikator menyusun bukti, memberikan alasan atau bukti terhadap beberapa solusi dan indikator menemukan pola atau sifat dari gejaala matematis untuk membuat generalisasi. Pada jawaban untuk point B yaitu membuktikan jawaban, Responden belum dapat melakukan pembuktian dengan tepat. Responden hanya menjelaskan prosedur pengerjaan yang telah dikerjakan sebelumnya namun untuk point membuat kesimpulan Responden dapat memberikan kesimpulan dengan benar.

Berikut ini adalah hasil pengerjaan responden yang merupakan salah satu mahasiswa yang berasal dari kategori sedang untuk soal nomor 2. Hasil pekerjaan mahasiswa tersebut disajikan pada Gambar 4.

2. Diketahui besar $\angle \mathrm{CED}=40^{\circ}$. Berapakah besar $\angle \mathrm{ACB}$ pada segitiga disamping?

a. Buktikan jawaban anda.

b. Buatlah kesimpulan berdasarkan jawaban anda

A
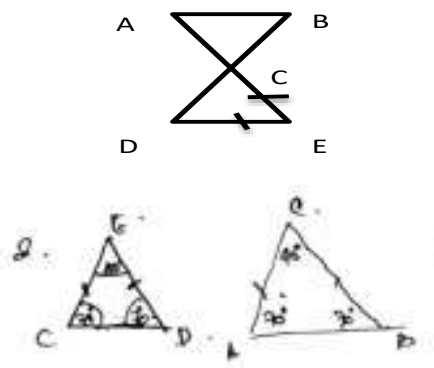

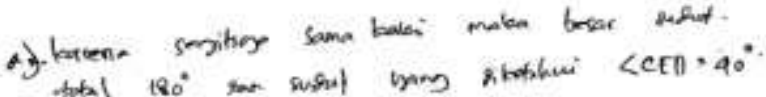

make $180^{\circ}-10^{\circ}+120^{\circ}$

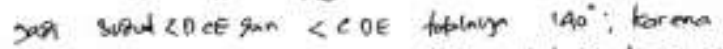

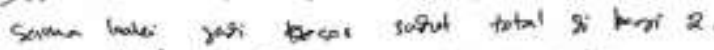

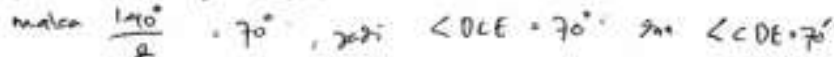

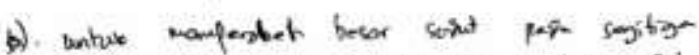

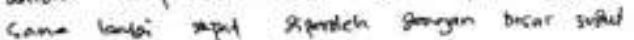

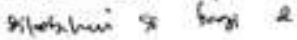

Fot $\angle A B C=\angle C O E \cdot 70^{\circ}$

$\angle D C E=\angle B A C=70^{\circ}$

$\angle C E D+\angle A C B \quad \cdot 90^{\circ}$

Gambar 4. Contoh jawaban soal nomor 2

Berdasarkan hasil tes tertulis, sebagaimana disajikan pada Gambar 4, Responden mengerjakan soal sesuai petunjuk umum sesuai instruksi yaitu mengambar walaupun tidak lengkap dengan apa yang diketahui namun sudah masuk dalam indikator. Responden tidak mengajukan dugaan, memanipulasi matematika dan menemukan pola 
atau sifat dari gejala matematis unutk membuat generalisasi namun langsung menuliskan jawaban akhir yang jawaban akhirnya juga kurang tepat pada gambar yang telah di buat. Untuk point A yaitu membuktikan jawaban R12 belum dapat melakukan pembuktian dengan tepat, namun untuk point membuat kesimpulan R12 dapat memberikan kesimpulan namun kesimpulan yang diberikan juga kurang tepat.

Berikut ini adalah hasil kerja responden, yang merupakan salah satu mahasiswa yang berasal dari kategori sedang untuk soal nomor 3. Hasil kerja responden disajikan pada Gambar 5.

3. Dalam suatu segitiga $\mathrm{ABC} \angle \mathrm{A}=35^{\circ}, \angle \mathrm{C}=85^{\circ}$, $\mathrm{D}$ terletak pada sisi $\mathrm{AB}$ dan $\mathrm{E}$ pada sisi BC.

a. Jika $\mathrm{DB}=\mathrm{BE}$, bagaimana cara menentukan besar $\angle B E D \ldots$

b. Tentukan besar $\angle B E D$ !

c. Buktikan jawaban anda.

d. Buatlah kesimpulan berdasarkan jawaban anda.

Jawaban Responden:

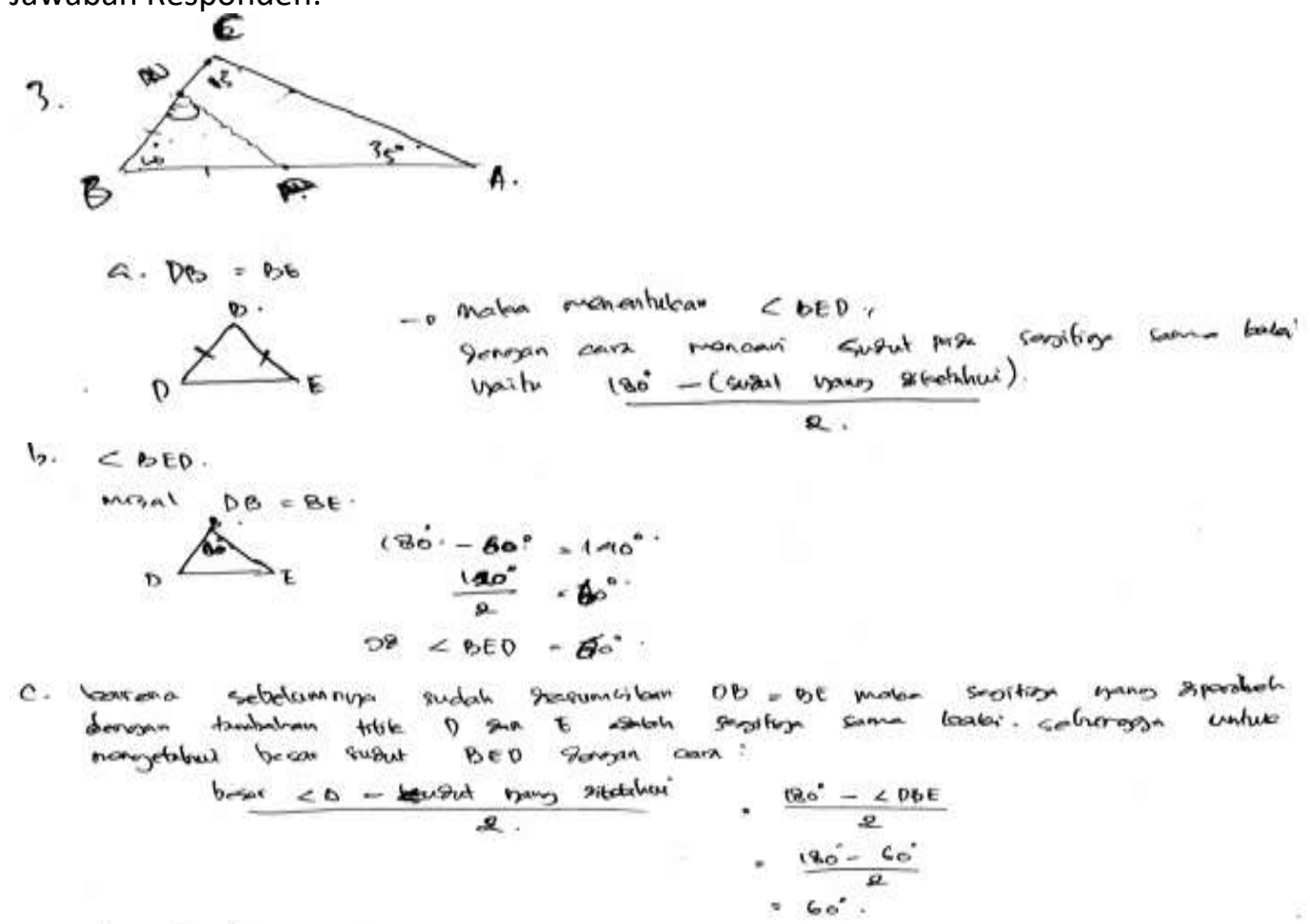

9. dow serition

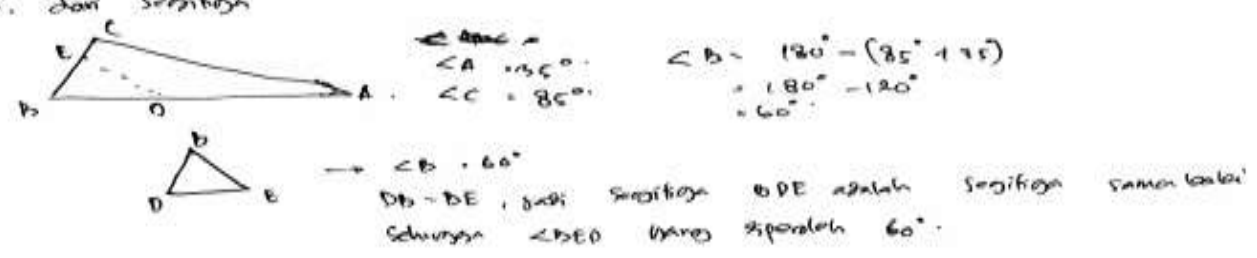

Gambar 5. Contoh jawaban soal nomor 3 
Berdasarkan hasil tes tertulis, sebagaimana disajikan pada Gambar 5, Responden mengerjakan soal sesuai petunjuk umum yang diperintahkan yaitu mengambar dengan apa yang diketahui sudah ada di dalam gambar. Responden mengajukan dugaan yang tertuang pada point $\mathrm{A}$, melakukan manipulasi matematika menyusun bukti, memberikan alasan atau bukti terhadap beberapa solusi yang ada pada point $\mathrm{B}$ dan $\mathrm{C}$ namun Responden tidak dapat menemukan pola atau sifat dari gejala matematis untuk membuat generalisasi dan tidak dapat memeriksa keshasihan argument atau tidak dapat membuktikan jawaban. Pada point membuat kesimpulan Responden dapat memberikan kesimpulan dengan tepat.

Berikut ini adalah hasil kerja dari responden yang merupakan salah satu mahasiswa dalam dari kategori sedang untuk soal nomor 4. Hasil kerja responden disajikan pada Gambar 6.

1.Ani mempunyai sebidang tanah berbentuk segitiga yang dapat ditulis $\triangle A B C$. Ani akan mengukur sudut sebidang tanah tersebut, dan dari hasil pengukuran sudutnya ditemukan bahwa $\angle \mathrm{ABC}=\angle \mathrm{ACB}=85^{\circ}$. Ani membuat sebuah patok $\mathrm{D}$ yang berada tepat ditengahtengah antara $\mathrm{B}$ dan $\mathrm{C}$ sehingga membuat garis dari titik $\mathrm{A}$ hingga $\mathrm{D}$ yang membagi dua tanah berbentuk segitiga tersebut. Ani juga membuat patok E antara A dan B yang membentuk sudut $\angle \mathrm{ACE}=15^{\circ}$. Pada titik perpotongan $\mathrm{AD}$ dan $\mathrm{CE}$ terdapat rumah yang disimbolkan dengan huruf $\mathrm{F}$.

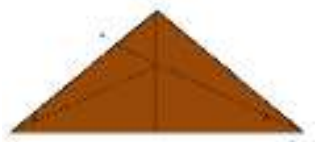

Jawaban Responden:

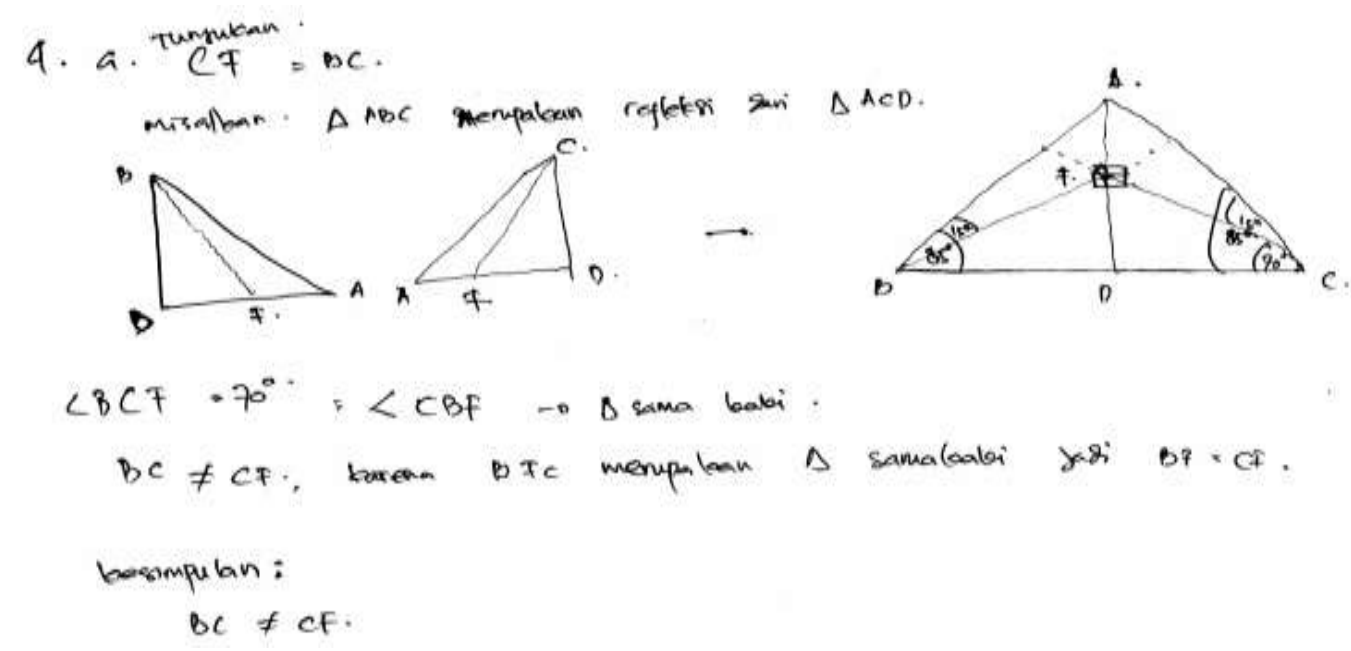

Gambar 6. Contoh jawaban soal nomor 4 
Berdasarkan hasil tes tertulis, sebagaimana disajikan pada Gambar 6, Responden mengerjakan soal sesuai petunjuk umum yang diperintahkan yaitu menyajikan gambar dengan apa yang diketahui sudah ada di dalam gambar. Responden mengajukan dugaan, melakukan manipulasi matematika, membuktikan jawaban dan menarik kesimpulan. Responden tidak menyusun bukti, memberikan alasan atau bukti terhadap beberaa solusi dan tidak menemukan pola atau sifat dari gejala matematis untuk membuat generalisasi.

Berikut ini adalah hasil kerja dari responden yang merupakan salah satu mahasiswa dalam dari kategori sedang untuk soal nomor 5. Hasil kerja responden disajikan pada Gambar 7.

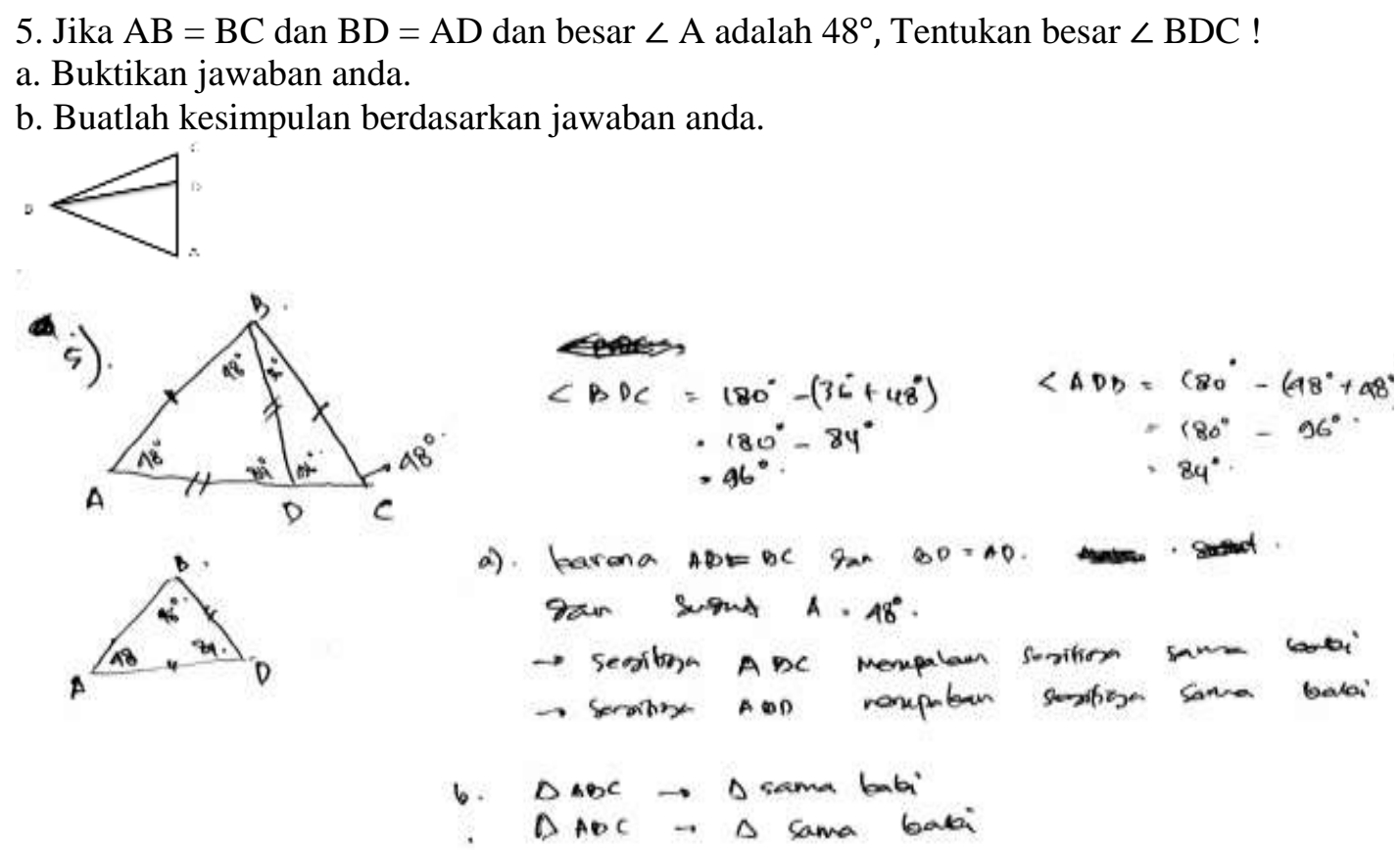

Gambar 7. Contoh jawaban soal nomor 5

Berdasarkan hasil tes tertulis, sebagaimana disajikan pada Gambar 6, terlihat bahwa Responden mengerjakan soal sesuai petunjuk umum yang diperintahkan yaitu menyajikan gambar, Responden melakukan manipulasi dan mendapatkan jawaban akhir. Responden menyusun bukti, memberikan alasan atau bukti terhadap beberapa solusi pada poin A yang harusnya membuktikan jawaban, namun tidak lengkap hanya sampai menyusun bukti. Namun Responden tidak mengajukan dugaan, tidak menemukan pola atau sifat dari gejala matematis untuk membuat generalisasi tetapi responden berhasil menyusun kesimpulan. 
Rendahnya kemampuan penalaran induktif mahasiswa Pendidikan Matematika UNIPA berdasarkan hasil analisis terhadap soal tes yang dikerjakan bersesuaian dengan hasil dengan hasil wawancara yang dilakukan. Pada umumnya ketidak-mampuan mereka mengerjakan soal tes disebabkan karena rendahnya kemampuan penalaran induktif matematika yang bersangkutan.

Kemampuan memahami matematika tidak terlepas dari kemampuan penalaran. Seorang mahasiswa dapat memahami materi dalam matematika jika mempunyai kemapuan penalaran yang baik. Menurut Agustin (2016), pada dasarnya setiap penyelesaian soal matematika memerlukan kemampuan penalaran, melalui penalaran siswa diharapkan dapat melihat bahwa matematika merupakan kajian yang masuk akal dan logis. Lebih lanjut, (Sinaga, 2016) menyatakan bahwa penalaran sangat dibutuhkan dalam matematika karena menyelesaikan suatu persoalan matematika harus dengan pemikiran, mengerti dan mampu menemukan sesuatu berdasarkan opini atau ketentuan yang sudah ada.

Brodie (2010) menyatakan bahwa: Mathematical reasoning is reasoning about and with the object of mathematics, yang mengandung pengertian bahwa penalaran matematis adalah penalaran mengenai objek matematika yang dalam hal ini adalah cabang-cabang matematika yang dipelajari seperti statistika, aljabar, geometri, dan sebagainya. Selanjutnya dijelaskan Kusumawardani, Wardono, dan Kartono (2018) bahwa penalaran matematis juga mensyaratkan kemampuan untuk memilah apa yang penting dan tidak penting dalam menyelesaikan sebuah permasalahan dan untuk menjelaskan atau memberikan alasan atas sebuah penyelesaian.

\section{SIMPULAN}

Berdasarkan hasil penelitian dan analisis yang dilakukan, maka dapat disimpulkan bahwa kemampuan penalaran induktif matematis yang dicapai mahasiswa pendidikan matematika UNIPA hanya mampu masuk dalam kategori sedang yaitu sebanyak 22 mahasiswa dari 72 mahasiswa dengan skor yang mereka peroleh berada pada interval 4160. Rendahnya kemampuan penalaran induktif matematika menyebabkan rendahnya kemampuan mahasiswa mengerjakan soal tes. Oleh karena itu, kemampuan penalaran induktif matematis mahasiswa pendidikan matematika UNIPA harus ditingkatkan terutama menyusun bukti, memberikan alasan atau bukti terhadap kebenaran solusi, menarik kesimpulan dari pernyataan dan memeriksa kesahihan argumen. 


\section{DAFTAR RUJUKAN}

Agustin, R. D. (2016). Kemampuan Penalaran Matematika Mahasiswa Melalui Pendekatan Problem Solving. Jurnal Pedagogi, 5(2): 179-188.

Atmaja, N.P. (2016). Evaluasi Belajar-Mengajar. Yogyakarta: Diva Press.

Brodie, K. (2010). Teaching Mathematical Reasoning In Secondary School Classroom. New York: Springer

Depdiknas. (2003). Standar Isi Mata Pelajaran Matematika Sekolah Menengah Atas dan $M A$. Jakarta: Pusat Kurikulum, Balitbang Depdiknas.

Depdiknas. (2004). Peraturan Dirjen Dikdasmen NNo. 506/C/PP/2004 tanggal 11 November 2004 tentang Penilaian Perkembangan Anak Didik Sekolah Menengah Pertama (SMP). Jakarta: Ditjen Dikdasmen Depdiknas.

Depdiknas. (2006). Permendiknas Nomor 22 Tahun 2006 Tentang Standar Isi. Jakarta: Depdiknas.

Kusumawardani, Wardono, dan Kartono. "Pentingnya Penalaran Matematika dalam Meningkatkan Kemampuan Literasi Matematika". Prosiding, Seminar Nasional Matematika, Universitas Negeri Semarang.

Rosita, C. D. (2014). Kemampuan Penalaran dan Komunikasi Matematis: Apa, Mengapa dan Bagaimana Ditingkatkan Pada Mahasiswa. Jurnal Euclid, 1(1), 33-45.

Rosnawati, R. (2011) Kemampuan Penalaran Matematika Siswa SMP Indonesia Pada TIMSS 2011. Prosiding, Seminar Nasional Penelitian, Pendidikan dan Penerapan MIPA, Yogyakarta: UNJ.

Sari, D. P. (2016). Berpikir Matematis Dengan Metode Induktif, Deduktif, Analogi, Integratif Dan Abstrak, Delta-Pi: Jurnal Matematika dan Pendidikan Matematika. 5(1): 79-89.

Shadiq, F. (2014). Pembelajaran Matematika: Cara Meningkatkan Kemampuan Berpikir Siswa. Yogyakarta: Graha Ilmu.

Sinaga, N. A. "Pengembanagan Tes Kemampuan Pemecahan Masalah dan Penalaran Matematika Siswa SMP Kelas VIII". PHTHAGORAS: Jurnal Pendidikan Matematika, 11(2): 169-181.

Sugiyono. (2015) Metode Penelitian Kuantitatif, Kualitatiif, dan R\&D. Bandung: Alfabeta.

Tanujaya, B., dan Mumu, J. (2016). Penelitian Tindakan Kelas: Panduan Belajar, Mengajar, dan Meneliti. Yogyakarta: Media Akademi.

Wulandari, E. (2011). Meningkatkan Kemampuan Penalaran Matematis Siswa Melalui Pendekatan Problem Posing Di Kelas VIII A SMP Negeri 2 Yogyakarta" Skripsi, Universitas Negeri Yogyakarta 